\title{
¿UN VESTIGIO FEUDAL DENTRO DEL RÉGIMEN LIBERAL? EN TORNO A LOS CENSOS EN LA LEGISLACIÓN DESAMORTIZADORA
}

\section{A FEUDAL REMAIN IN THE LIBERAL REGIME? ON THE CENSOS IN THE DESAMORTIZATION LAWS}

\author{
David Martínez-Vilches \\ Universidad Complutense de Madrid (España) \\ ORCID: https://orcid.org/0000-0002-5157-2880
}

Recibido el 19-9-2017 y aceptado el 6-2-2018

\begin{abstract}
Resumen: Este artículo examina el cambio jurídico y social que supuso la desamortización de censos durante la revolución liberal en España. La legislación desamortizadora transformó la propia concepción de los censos como formas de explotación de la tierra y el trabajo al admitir su redención y, por tanto, el acceso de los censatarios a la plena propiedad de la tierra anteriormente acensuada. Esto no solo repercutía en el fenómeno desamortizador general, sino que también permitió acomodar estas figuras jurídicas de origen antiguo al nuevo régimen liberal, pues diferenciaba entre los censos de los bienes nacionales, redimibles a través de la normativa desamortizadora, y los censos entre particulares, que permanecían como derechos de propiedad privada, a pesar de que no fuesen de «propiedad perfecta». También se analizan proyectos de reforma como los de los ilustrados o el de Flórez Estrada, que nos revelan una mayor complejidad respecto a las ideas liberales sobre la propiedad de la tierra, más allá de las disposiciones finalmente llevadas a cabo.
\end{abstract}

Palabras clave: legislación desamortizadora, revolución liberal, censos, propiedad de la tierra.

Abstract: This article examines the legal and social change which implied the desamortization of censos (liens on real right) during the liberal revolution in Spain. Desamortization laws transformed the understanding of censos as ways of land and labour exploitation due to they admitted its redemption 
and, therefore the access of the censatarios (who paid an annuity because of the charges upon their estates) to the ownership of the previously charged property. This not only had an effect on the general process of desamortization, but it also allowed for the adjustment of these old legal institutions to the new liberal regime, as the law distinguishes between the censos charged upon nationalised properties, redeemable through the legislation, and those established among individuals, which remained as private property rights, despite they were not «perfect property» rights. We also analyse reform projects, such as those of the enlightened men or Flórez Estrada, which reveal a greater complexity with respect to liberal ideas about land ownership, beyond the provisions carried out in the end.

Keywords: desamortization laws, liberal revolution, censos, land ownership. 


\section{Introducción}

Aquí abordamos un fenómeno muy específico dentro de la reforma agraria liberal, y más concretamente de la desamortización, que la historiografía ha venido tratando desde hace tiempo, pero que, por su complejidad, permanece todavía hoy inexplorado en muchas de sus dimensiones. Nos referimos a la desamortización de censos, un capítulo importante dentro de la actuación desamortizadora del Estado liberal en el siglo XIX, aunque eclipsado por las enajenaciones que se efectuaron en subasta pública. Su relevancia radica en la amplia capacidad de cambio jurídico y social que esta medida suponía en el panorama agrario español durante la revolución liberal, en dos niveles. En un primer nivel, su implementación efectiva significaba el acceso de muchos llevadores de censos a la completa propiedad de la tierra acensuada, es decir, incidía en la reconfiguración de la estructura de la propiedad de la tierra ${ }^{1}$. En un segundo nivel, y el que es objeto de atención aquí, la desamortización de censos introducía una transformación en la concepción de las formas de explotación de la tierra y el trabajo, estableciendo el principio de redimibilidad de este tipo de gravámenes de antiguo origen sobre los bienes nacionalizados, pero sin afectar a los constituidos por otros particulares, que eran considerados como derechos de propiedad, si bien se trataba de una propiedad no plenamente libre y, en algunos casos, incluso dividida en dominios ${ }^{2}$.

Nuestra hipótesis de partida es que la desamortización $-\mathrm{y}$ la reforma agraria liberal en un sentido más amplio - cambió de forma decisiva el carácter de los censos, instituciones que, por otra parte, ya habían sufrido muchas transformaciones a lo largo de su existencia. Ello nos conduce a rechazar nociones simplificadoras que a veces se han atribuido a estas figuras jurídicas en el siglo XIX, como la de que son vestigios del feudalismo porque la clase política liberal tuvo que pactar con la antigua nobleza, lo que impidió alcanzar el horizonte de la «propiedad perfecta». Sin negar que la compleja realidad de construcción del Estado liberal en España también contempló circunstancias como esa, el problema de los censos no radica en este extremo, o al menos no únicamente. Fue preci-

\footnotetext{
${ }^{1}$ Para una introducción a esta cuestión, véanse los trabajos de Díez Espinosa, 1986a y 1993; y Cordero Torrón, 2012.

2 Desde una óptica jurídica centrada en el Derecho de propiedad, con referencias también a la desamortización, véanse Clavero, 1980 y 1981; y Peset y Blasco, 1992.
} 
samente la voluntad liberal por «sacralizar» la propiedad, en expresión de Rosa Congost, lo que acabó blindando todo derecho de propiedad, también de «propiedad imperfecta» ${ }^{3}$. Sin embargo, ello no implica una supervivencia del feudalismo dentro del orden liberal, pues no todos los censos revestían un carácter feudal, sino solo aquellos que se configuraban en el marco de explotación de la tierra y el trabajo del señorío, por lo que la legislación antiseñorial también trató el tema de los censos. En suma, que estas instituciones viniesen de un mundo anterior al liberalismo no significa que mantuviesen en él todos los contenidos que se les atribuía en el Antiguo Régimen, sino que pudieron encontrar acomodo en el orden liberal, y la desamortización de censos constituye un fenómeno fundamental desde la que abordar esta cuestión que replantea la categoría de estas figuras jurídicas en su propio tiempo. Descubrir el cambio social que subyace en el cambio jurídico es, por tanto, nuestro objetivo fundamental a la hora de analizar la desamortización de censos.

\section{Los censos: definiciones previas}

Es exigible antes de cualquier otra consideración establecer qué es lo que se entiende por «censo». Una primera aproximación de carácter jurídico sería la que definiese censo como contrato a través del cual determinados bienes quedan sujetos al pago de un canon anual a cambio de la recepción de un cantidad de dinero o del dominio pleno o menos pleno de dichos bienes, siendo esta perpetua o indefinida en su temporalidad, aunque redimible. De ello se extrae que es un derecho real, en tanto que se carga sobre los bienes sujetos, y concretamente un derecho real in faciendo, ya que obliga al receptor de dichos bienes a realizar el pago de la pensión. En cuanto a su tipología, existen tres variedades de censos: enfitéutico, cuando se cede el dominio útil de una finca, gravándolo con una pensión que ha de pagar el receptor (censatario, en este caso denominado también enfiteuta) al titular del dominio directo o eminente (censualista) como reconocimiento de ese dominio; consignativo, cuando el censualista cede una cantidad de dinero (principal) al censatario, y este es obligado a pagarle una pensión que queda gravada sobre alguno de sus bienes inmuebles como garantía de pago; y reservativo, cuando el censualista cede al

\footnotetext{
3 Congost, 2000.
} 
censatario el pleno dominio de un inmueble, a cambio del derecho de percibir sobre ese inmueble un canon anual.

Todo lo recogido anteriormente es lo que se presenta en el Código Civil de 1889. El problema del historiador es que no puede operar con categorías jurídicas cerradas y extemporáneas. Si lo que pretendemos es contemplar las transformaciones que produjo la desamortización de censos, no podemos utilizar definiciones cerradas posteriores. Los censos proceden de un mundo anterior al liberalismo y, sin embargo, la legislación liberal los acogió. Pudiera argumentarse que son derechos feudales que sobrevivieron a la caída del Antiguo Régimen porque la revolución liberal adoptó en España la «vía prusiana» de entendimiento entre la burguesía y la antigua nobleza. Sin embargo, los censos no tienen nada que ver con derechos señoriales, sino que tienen un origen crediticio. La enfiteusis es otro asunto a valorar, pues no es un censo en su origen. Dependerá en ambos casos del contexto en el que se den estas figuras jurídicas para establecer su «feudalidad». Hay, por tanto, que aclarar estos interrogantes que oscurecen la comprensión de estas figuras jurídicas dentro de su propio régimen de historicidad antes de pretender cualquier otro tipo de averiguación.

Los censos son, en su génesis histórica, rentas originadas para satisfacer el crédito en un mundo que prohibía la usura. La desconfianza del judaísmo hacia el dinero fue contagiada al cristianismo y elevada a categoría de norma en la época medieval, prohibiendo todo tipo de interés en muchas de las transacciones que se efectuaban. Dadas estas limitaciones, las necesidades pecuniarias desde entonces habrían de ser solventadas a partir de compraventas que, para alejar toda suspicacia eclesiástica, se configuraron tomando el esquema de relación señorial como enajenaciones de rentas vinculadas a tierras en forma de gravamen. En estos márgenes cabían dos posibilidades. La primera era que un propietario vendiese una propiedad a cambio de una pensión que se cargaba sobre dicha propiedad y se reservaba para el vendedor. La segunda era que el propietario, en caso de urgente liquidez, vendiese una renta a cambio de dinero (llamado principal), y la satisfacción de dicha renta quedaba consignada sobre un inmueble de su propiedad como garantía. Estas fórmulas son, como su propia definición sugieren, el censo reservativo y el consignativo, respectivamente. Distintos textos canónicos y legislativos fueron precisando esta materia desde el siglo XIII, quedando más o menos definida a inicios de la Edad Moderna, aunque observando muchos matices y casuísticas particulares en esos contornos 
generales ${ }^{4}$. Esos caracteres se plasmaron en la definición más aceptada de censo en el Antiguo Régimen hispano, la de Feliciano de Solís. Para este jurista, censo era «un contrato instituido según la costumbre en el que uno vende y otro compra el derecho a ciertos réditos pagados cada año en dinero» ${ }^{5}$. Por tanto, se trataba de una compraventa con tres elementos: el vendedor, el adquiriente y el derecho de percibir una renta anual. No se alude, en cambio a los bienes raíces sobre los que recae el censo, que es otro de sus caracteres fundamentales, y que es el que aparece más destacado en la explicación de Sebastián de Covarrubias: «Comúnmente llamamos censo, el que tenemos cargado sobre algunos bienes raízes $[$ sic $]{ }^{6}$.

Siguiendo con Solís, en su obra recoge dos especies de censos que se identifican fácilmente con el reservativo y el consignativo. Este último lo define como aquel «que es muy frecuente en España, y que es procurado con el pago del precio sobre una cosa propia o una persona [e] instituye una pensión anual para el otro, perpetua y con pacto de retroventa» ${ }^{7}$, por tanto, perpetuo pero redimible por medio del pacto de retroventa, que consistía en la devolución del principal. En cuanto al reservativo, Solís señalaba que era en el que «una cosa es concedida a alguien en pleno derecho, de modo que el receptor tiene tanto el dominio directo como el útil, reservando al antiguo señor [de la cosa] alguna pensión que ha de ser pagada anualmente en reconocimiento de [su] anterior dominio» ${ }^{8}$, transfiriendo aspectos de la enfiteusis como la división de dominios y la pensión en reconocimiento del dominio primitivo al censo reservativo, aunque poco tenían que ver - si se trasmite tanto el dominio útil como el directo no se produce tal división, y la pensión no se satisface en virtud de un reconocimiento al antiguo propietario, sino por el propio objeto de la compraventa de la propiedad - .

Al atribuir una división de dominios al censo reservativo, la definición de Solís nos pone sobre aviso de la progresiva asimilación entre enfiteusis y censos que se produjo ya en el siglo XVI, y que se mantendrá a la hora de tratar esta materia hasta el siglo XIX. Así, encontramos cierta idea

${ }^{4}$ Clavero, 1977; Ladero Quesada, 1990-1991; Fiestas Loza, 1993-1994.

5 Solís, 1594, f. 51 r (todas las traducciones son del autor). Cf. Mora Cañada, 1987; Pereira Iglesias, 1994-1995.

6 Covarrubias, 1611, f. $271 \mathrm{v}$.

7 Solís, 1594, f. 16 v.

8 Solís, 1594, f. 4 v. 
que también aplica la división de dominios a los censos consignativos por medio de una ficción jurídica en la que no se vende el derecho de percibir una renta anual, sino toda la propiedad, que luego se devuelve a su anterior propietario con el dominio útil gravado por el censo. Ello configura un censo consignativo perpetuo, pero $-\mathrm{y}$ aquí es donde radica la novedosa contradicción - sin pacto de retroventa, es decir, irredimible:

Pedro tiene una casa: oblígase a Juan a darle todos los años cien reales por mil que recibe de él, dexando obligada aquella para la satisfacción de la referida anual suma, con que se va cargando, omitida su paga. Finge el Derecho, que comprada la casa por Juan en el precio de los mil reales, se la vuelve a Pedro; y transfiriendo en él el derecho, y dominio útil de ella, queda este con la obligación de contribuirle la expresada suma, o censo. ${ }^{9}$

Esto refleja que los contornos originales del censo fueron tensionados de forma inédita, pues, como señalaba el fiscal del Consejo Supremo de Castilla para el caso anteriormente citado, «si el principal era equivalente a todo el valor de la finca, y con respecto al mismo se capitulaban los réditos, faltaba la justicia original del contrato» ${ }^{10}$. Al margen de este caso peculiar, ¿cuál era la situación de los censos en los momentos inmediatamente anteriores a la crisis del Antiguo Régimen? Dentro de difuminados márgenes, se aprecia los caracteres principales que enunciaba Solís: su elemento central es la renta anual, aunque la relación contractual en la que está implicada había adquirido nuevos contornos, muchos de ellos tomados de la enfiteusis, que es la figura jurídica que ahora debemos analizar.

El derecho real de enfiteusis tiene orígenes distintos y una estructura jurídica notablemente diferente a los censos, a pesar de que se observen paralelismos debido a las formas en que se manifiesta - renta que grava, esta vez no una propiedad, pero sí un dominio - . Incluso, para el caso de España, cuando los juristas del siglo XIX incluyeron la enfiteusis dentro de los censos, la legislación liberal no olvidó sus divergencias y estableció peculiaridades, tanto en lo que respecta a la desvinculación señorial como a la desamortización. Las dificultades no acaban ahí, sino que se van sumando en cuanto queremos trazar una panorámica de su evolución previa a la propia revolución liberal. No es solo que la enfiteusis tenga una larga

${ }_{10}$ Cornejo, 1779-1784, I, p. 126. Véase también la exposición que hace Sala, 1803.

${ }^{10}$ Elizondo, 1792, IV, p. 12. 
historia que arranca desde la Antigüedad, sino que en toda esa evolución las doctrinas jurídicas no la definieron de la misma forma. Y ello sin entrar en su aplicación práctica, que hubo de contemplar múltiples variaciones, algunas regionales y otras de tipo más circunstancial.

Aquí no podemos plantear ni toda la riqueza de matices ni todos los problemas que esta forma enajenamiento suscitó, pero sí debemos esbozar sus caracteres generales. Para lo que nos afecta, el mundo hispánico medieval heredó la enfiteusis latina, definida en sus caracteres principales por la legislación romano-bizantina de la Tardoantigüedad. Este componente clásico se aprecia con claridad en las Partidas de Alfonso X, cuya normativa presenta la enfiteusis como un enajenamiento de naturaleza especial, a mitad de camino entre el arrendamiento y la venta, pero que, en definitiva, nace de la libre voluntad de las partes contratantes, que acuerdan la cesión perpetua o temporal de una finca inmueble «a censo», esto es, a cambio de un canon anual ${ }^{11}$. Asimismo, los juristas del Rey Sabio nos presentan los tres rasgos básicos que hacen reconocible esta institución y que caracterizan las relaciones entre enfiteuta y al propietario. La primera es la pérdida de la finca dada a enfiteusis por impago del enfiteuta durante cierto tiempo, dos años en caso de que se trate de bienes eclesiásticos y tres para bienes legos. En segundo lugar, la preferencia de compra que tiene el señor de la cosa si el enfiteuta desea venderla. Finalmente, en caso de verificarse tal venta, el tributo que ha de pagar el enfiteuta, no más de un $2 \%$ del precio $^{12}$. Hasta aquí, ningún elemento de feudalidad, medieval o «medievalizante» puede percibirse. Únicamente parece apreciarse cierta asimilación de práctica señorial en la posibilidad que tenía el señor de quitar la finca por impago sin necesidad de intervención judicial, pero ello no constituye un elemento definitorio, al menos en su comprensión ${ }^{13}$.

Sin embargo, esa figura jurídica de contornos clásicos en seguida fue cargada de un contenido señorial por parte de la doctrina jurídica. Posiblemente la Iglesia fue la que mantuvo de forma más prístina esas raíces antiguas en sus enfiteusis, pero al final la enfiteusis se articuló reflejándose en el espejo donde toda la sociedad deseaba mirarse: la relación señorial. En consecuencia, se aplicó la teoría del dominio dividido, que otorgaba

${ }^{11}$ Código de las Siete Partidas, partida I, tít. XIV, ley III y partida V, tít. VIII, ley XXVIII; 1848, I, p. 231 y II, p. 664. Cf. Ortuño Sánchez-Pedreño, 1993.

12 Código de las Siete Partidas, partida V, tít. XIV, ley XXIX; 1848, II, p. 671.

13 Seguimos en líneas generales el excelente trabajo de Clavero, 1986. 
a propietario y enfiteuta derechos dominicales que de alguna forma remedan las relaciones de la nobleza entre señor y vasallo. Es así como se acaba distinguiendo entre dominio directo del señor y dominio útil del enfiteuta, un esquema que no se agota en la dualidad, pues podía darse, al igual que la relación feudovasallática, a distintos niveles que configuran un entramado de derechos. Derechos y subordinaciones, pues esos tres rasgos que antes enumerábamos como característicos de esta institución se impregnan de jurisdicción señorial, de «feudalidad», por así expresarlo, adquiriendo su denominación particular: «comiso», la reversión por impago, que acaba convertida en una vuelta del dominio útil al titular del directo y, por tanto, la consolidación de la propiedad; «tanteo», el derecho preferente del señor a la compra del dominio útil; y el «laudemio», el porcentaje que el enfiteuta estaba obligado a pagar al señor en caso de venta de su dominio, que se otorgaba a título de reconocimiento (del latín laudare, «alabar»).

Avanzando el tiempo, la consolidación del sistema socio-económico del Antiguo Régimen trajo novedades en esta materia. Por supuesto, la aplicación de la teoría del dominio dividido seguía vigente, pero sus perfiles perdieron nitidez. El enfiteuta se convirtió en terrateniente y su derecho adquirió cierta connotación de propiedad, incluso de perpetuidad. Es difícil señalar alguna razón convincente para este cambio. Bartolomé Clavero apunta a que el decaimiento político del mundo de señores y vasallos produjo en las instancias inferiores del señorío esta mutación, a lo que se unía un acercamiento entre censos y enfiteusis ${ }^{14}$. Esto último pudiera ser más un síntoma que una causa, pero, en cualquier caso, es evidente. Los propios juristas de las Partidas habían escrito «censo» al referirse a la renta que generaba el contrato enfitéutico. Ahora los juristas de la Edad Moderna hacían lo mismo, pero iban más allá, integrando censos y enfiteusis en un mismo capítulo y extrapolando matices de una a otra parte. Ello explica la confusión en lo que respecta al censo reservativo que mostraba Feliciano de Solís, al atribuirle una división de dominios que no se producía de ninguna manera.

Parece que la comprensión histórica de la enfiteusis es un juego de equilibrios entre permanencias y cambios constante: un enajenamiento de naturaleza especial primero, una cesión con división de dominios después, casi un nuevo tipo de censo finalmente. Avanzando el tiempo, el Siglo de

${ }^{14}$ Clavero, 1986, pp. 482-484. 
las Luces no clarificó el asunto, sino todo lo contrario. A lo largo de esta centuria se hizo patente un conflicto en torno a un tipo de enfiteusis que tenía lugar en el reino de Galicia y sus zonas limítrofes, el foro. Su articulación a distintos niveles configuraba un entramado de relaciones que situaba entre los señores - titulares del dominio directo- y los foreros - titulares del dominio útil - una instancia intermedia, los llamados «señores medianeros». Estos eran foreros, pero también señores, y por tanto, su interés estribaba en percibir rentas superiores a las que pagaban. En el siglo XVIII, los titulares directos plantearon cambiar esa situación por distintos medios - negativa a renovar pactos, ejecución de despojos, elevación de rentas-, pero fueron los «señores medianeros» bien representados en las instituciones del reino, quienes hicieron prevalecer sus derechos de forma más eficaz. Así, en 1763 Carlos III dictó una provisión real suspendiendo de forma provisional los despojos mientras se cumpliese con el pago de los cánones, medida que luego se haría extensiva a las zonas de Asturias y León en las que también hubiese foros. Estos quedaban así como un tipo de enfiteusis - por tanto, irredimible - perpetuada en la práctica. Hay un intento similar para conseguir en Cataluña la perpetuidad en las rabassas - otro tipo de enfiteusis que llevaba aparejado el cultivo de vides y duraba la vida de los dos tercios de cepas plantadas-, pero esta vez los titulares directos consiguieron impedir que prosperara.

En fin, todo ello nos presenta un panorama relativo a censos y enfiteusis bastante confuso en vísperas de la revolución liberal. Por una parte, se mantenían los censos consignativos y reservativos con sus caracteres particulares, aunque con algunas notas que reflejan la influencia de la enfiteusis. Por otra, esta se confunde con aquellos, e incluso algunas fuentes ya se refieren al «censo enfitéutico». Confusión, en suma, pero distinción más o menos clara a falta de una sistematización que agrupe definitivamente estas instituciones. Habrá que esperar al siglo XIX para que la enfiteusis se introduzca para siempre en el capítulo de censos, mediando toda la revolución liberal y su desarrollo legislativo.

\section{Las contradicciones de las Luces: entre el horizonte ilustrado y la realidad hacendística}

Las primeras medidas orientadas a la eliminación de censos se producen desde finales del siglo XVIII, motivadas por los problemas que acuciaban a la Hacienda. Sin embargo, la opinión ilustrada de los censos no 
podía ser más positiva. En un momento en que se plantea la reforma agraria para solucionar los obstáculos que impedían el progreso de la agricultura española, los censos concordaban con el sentir general de quienes reflexionaban sobre cómo conseguir un mejor reparto de la propiedad de la tierra sin provocar grandes convulsiones. Desde luego, este era el pensamiento del intendente sevillano Pablo de Olavide, que pudo llevar a la práctica en la repoblación de Sierra Morena. Olavide veía en los censos reservativos y la enfiteusis unos instrumentos perfectos para promocionar asentamientos estables que favoreciesen la agricultura y diesen sustento a quienes carecían de tierras, al mismo tiempo que se evitaba una confrontación con los grandes propietarios ${ }^{15}$. Sobre el censo consignativo, en un sentido similar se postulaba Manuel Sisternes y Feliu, fiscal del Consejo y Cámara de Castilla en los años finales de Carlos III, que lo contemplaba como un medio de obtención de liquidez para que los campesinos mejorasen sus cultivos sin necesidad de comprometer excesivamente su patrimonio:

Lejos de creer que los censos son perjudiciales a la Agricultura, los he tenido y tengo por útiles, y perjudicial su falta. Porque el que quiera mejorar su hacienda, sacar nuevas tierras, darlas regadío, y aumentar su producto por medios costosos, no teniendo dinero para ello, hallaba el modo de conseguirlo, tomando un censo que podía redimir a su arbitrio quando quisiere ${ }^{16}$.

Posiblemente sea en el Informe del asturiano Gaspar Melchor de Jovellanos donde más sistemáticamente se observa esta opinión ilustrada favorable a los censos como mecanismo para hacer partícipes de la riqueza agraria a una mayor población. En 1777 el Consejo de Castilla había pedido a la Sociedad Económica Matritense de Amigos del País un informe que sintetizase todas las ideas que desde años anteriores se venían aportado para la elaboración de un proyecto de ley agraria. Su confección acabó recayendo en 1787 en Jovellanos, que dispuso de toda la documentación del Consejo sobre el expediente de ley agraria para llevar a feliz término su tarea, lo que no ocurrió hasta 1795 con la publicación del In-

${ }^{15}$ El informe de Pablo de Olavide en Memorial ajustado, 1784, ff. 175v.-178v. y su dictamen en ff. 246r-250r. Véase a este respecto Perdices Blas, 1989b y Merchán Álvarez, 1997.

16 Sisternes y Feliu, 1786, pp. 81-82. 
forme. Al igual que para Olavide, cuya labor había vivido en primera persona ${ }^{17}$, los censos eran la estrategia más eficaz para mejorar la agricultura en sus aspectos cualitativos y cuantitativos, empezando por las tierra concejiles: «Las tierras concejiles divididas y repartidas en enfiteusis o censo reservativo [...] podrían ofrecer establecimiento a un gran número de familias, que exercitando en ellas su interés particular, las harían dar considerables productos, con gran beneficio suyo y de la comunidad a que perteneciesen» ${ }^{18}$. En cuanto a los bienes eclesiásticos, Jovellanos opta por la prudencia - aunque eso no lo libraría de un expediente inquisitorialen su prosa:

La Sociedad, Señor, penetrada de respeto y confianza en la sabiduría y virtud de nuestro clero, está tan lejos de temer que le sea repugnante la ley de amortización, que antes bien cree que si S. M. se dignase de encargar a los reverendos prelados de sus iglesias que promoviesen por sí mismos la enagenación de sus propiedades territoriales para volverlas a las manos del pueblo, bien fuese vendiéndolas y convirtiendo su producto en imposiciones de censos o en fondos públicos, o bien dándolas en foros o en enfiteusis perpetuos y libres de laudemio, corrían ansiosos a hacer este servicio a la patria con el mismo zelo y generosidad con que la han socorrido siempre en todos sus apuros ${ }^{19}$.

Finalmente, al referirse a la posibilidad de ceder en enfiteusis bienes vinculados de los mayorazgos, argumenta por qué esta figura jurídica redunda en beneficio de la agricultura y toda la sociedad:

porque nunca será más activo el interés de los colonos, que quando sean copropietarios, y quando el sentimiento de que trabajan para sí y sus hijos los anime a mejorar sus suertes y perfeccionar su cultivo. Esta reunión de dos intereses y dos capitales en un mismo objeto, formará el mayor de todos los estímulos que se pueden ofrecer a la agricultura ${ }^{20}$.

Puede parecer ambigua la propuesta ilustrada ante nuestros ojos. La igualdad social figura como horizonte deseable, pero ello requería unas medidas que no se podían tomar en el contexto de una monarquía absoluta

\footnotetext{
17 Perdices Blas, 2013a.

18 Jovellanos, 1795, p. 17.

19 Jovellanos, 1795, pp. 63-64.

20 Jovellanos, 1795, p. 74.
} 
del Antiguo Régimen. A ello se suma el temor a la revolución tras lo ocurrido en el verano de 1789 en Francia, lo que levantaba mayores suspicacias, si cabe, hacia cualquier actitud de reforma. Por todo ello, los censos y la enfiteusis, de presencia inmemorial en las relaciones económicas del país, se perfilaban como el instrumento más adecuado para que aquellos que menos tenían pudiesen participar de la renta de la tierra que percibían las élites, sin necesidad de imposiciones ni cambios traumáticos. Ello sin olvidar que el último objetivo era puramente económico: la estabilidad de esos campesinos acabaría mejorando la agricultura. No obstante, hay elementos novedosos, como eliminar el laudemio para las enfiteusis que se constituyeran en las propiedades eclesiásticas, un matiz de evidente liberalismo económico que avanza lo que ocurrirá con este tipo de instituciones durante la revolución liberal. La propuesta, aunque con sus límites, es un combate a la amortización en toda regla, pero con los instrumentos disponibles en el Antiguo Régimen: censos y enfiteusis ${ }^{21}$.

Sin embargo, la política efectiva en materia de censos y otros derechos similares tuvo otra línea: aquella que pudieron orientar quienes más intereses tenían puestos ellos y quienes mejor pudieron defenderlos. Como ya anticipamos, los intermediarios forales gallegos - bien representados en las instituciones del Reino de Galicia - consiguieron hacer prevalecer su posición y en 1763 Carlos III dictó una real provisión en la que se suspendía cualquier pleito sobre el tema de los foros, «sin permitir tengan efecto despojos, que se intenten por Dueños del Directo Dominio, pagando los Demandados, y foreros el Canon, y Pensión, que actualmente, y hasta ahora han satisfecho a los Dueños, ínterin, que por N. R. P. a consulta de los del nuestro Consejo, se resuelva lo que sea de su agrado» ${ }^{22}$. Esto significaba la perpetuación de los foros, asemejando la no renovación de los mismos al despojo y, por tanto, convirtiendo estos contratos de larga duración en cesiones perpetuas. El forista pasaba a ser un terrateniente y esta situación de cesiones a varios niveles agravó el carácter minifundista del agro gallego, a la vez que la renta de la tierra se repartía entre muchas manos que no la cultivaban.

Es evidente el contraste entre la opinión ilustrada y la política efectiva en materia de censos en toda la segunda mitad del siglo XVIII. Asimismo, las necesidades de la Hacienda, ya desde época de Carlos III, inclinaron

21 Llombart, 2013, pp. 77-114.

22 El texto de la Real Provisión de 11 de mayo de 1763 en Jove y Bravo, 1883, pp. 325-327, cita en p. 327. 
la actuación legislativa en contra de este tipo de instituciones. Durante los años inmediatamente finales al cambio de siglo, fruto de las guerras con Francia y Reino Unido y de un sistema de financiación - la emisión de vales - ruinoso, la situación financiera era insostenible. El gobierno de Mariano Luis de Urquijo recurrió en septiembre de 1798 a la desamortización de ciertos bienes eclesiásticos y, en tanto algunos de ellos estaban gravados con censos, una real orden del 18 de diciembre determinaba cómo se procedería con ellos. Los redimibles pasarían como depósito a la Caja de Amortización con el interés correspondiente de un 3\% hasta que el propietario determinase qué hacer; a excepción de los que pertenecían a establecimientos piadosos, que quedarían subrogados en la Caja de forma definitiva. Por el contrario, los censos perpetuos o enfitéuticos se mantenían en las fincas así gravadas, si bien la venta quedaba libre de laudemio $^{23}$. Hay que destacar que aquí ya no se habla de enfiteusis sino de «censos perpetuos o enfitéuticos», lo que refleja la consideración de la enfiteusis como una figura censual, aunque se le asignaba un procedimiento distinto al de los censos de tipo crediticio. No obstante, la legislación finisecular sobre censos fue más allá de la desamortización y estuvo también encaminada a dar solución al problema de los vales reales. En este sentido, una real cédula de 10 de noviembre de 1799 permitía redimir todo tipo de censos con vales reales, que, una vez presentados en la Tesorería General, en las del Ejército o en las provinciales, serían sellados y extinguidos, pasando la Real Hacienda a pagar anualmente su interés al antiguo censualista hasta su amortización ${ }^{24}$.

Toda esta legislación no solo atendía las urgentes necesidades de la Hacienda, sino que también podía beneficiar a muchos censatarios ${ }^{25}$. Sin embargo, las facilidades otorgadas para la redención de gravámenes ponían en peligro los dominios señoriales, pues muchos de estos contemplaban la enfiteusis como mecanismo de explotación de la tierra y el trabajo.

${ }^{23}$ Real Orden de 18 de diciembre de 1793, en Novísima Recopilación, lib. X, tít. XV, ley XX; 1805-1807, V, pp. 87-88.

${ }^{24}$ Real Cédula de 10 de noviembre de 1799 , cuyo procedimiento quedaba concretado por un reglamento de 17 de abril de 1801, ambos en Novísima Recopilación, lib. X, tít. XV, leyes XXI y XXII; 1805-1807, V, pp. 88-92. Sobre la crisis hacendística del reinado de Carlos IV y esta primera fase desamortizadora, véase el clásico estudio de Richard Herr, 1971.

${ }^{25}$ Efectivamente, se constata la importancia de la desamortización de censos en esta etapa en zonas como Cataluña (Herr, 1991), Andalucía (Gómez Oliver y González de Molina, 1995) y Extremadura (Naranjo Sanguino y Roso Díaz, 2003). 
Es por ello que en 1804 se tomaron medidas para poner freno a esa vocación redencionista. El 15 de septiembre Carlos IV otorgó una real cédula que dejaba libertad para la constitución de contratos censuales, en los que «se podrían poner los pactos, vínculos y condiciones que se tengan por convenientes», a la vez que los censatarios de censos redimibles podían renunciar a las «facultades»-facilidades - de la legislación anterior ${ }^{26}$. Ahí se avanzaba lo que el reglamento de 17 de enero de 1805 acabó disponiendo. Tras una declaración de posibilidad de redención de todo tipo de censos, este texto sentenciaba:

que no podrán redimirse los dominios solariegos, o establecimientos de carta-puebla; ni las prestaciones de la octava, décima, undécima u otra parte alíqüota de los frutos de uno o más predios, quando no conste haber sido adquiridas por precio cierto; ni finalmente los foros temporales, como los del Reyno de Galicia y Principado de Asturias, por ahora, y mientras que el Consejo acuerde y me consulte, con vista del expediente general instruido en su razón, lo que estimare conveniente ${ }^{27}$.

Los foros temporales, por tanto, irredimibles - pero perpetuos debido a la vigencia de la real provisión de $1763-$, no quedaban incluidos en la posibilidad de redención, pero sí los consignativos, y los otros tipos de censos enfitéuticos y reservativos. En suma, y aunque puede argumentarse que no afecta a todas las instituciones censales, sin duda este reglamento de 1805 sienta las bases de lo que luego será la legislación liberal. Y esto no solo por esa posibilidad de redención, sino también -y muy importante - por conjugar tal posibilidad con la salvaguarda de los dominios territoriales de la nobleza.

El panorama hasta los prolegómenos de la crisis del Antiguo Régimen no puede ser más contradictorio. Los ilustrados plantearon unos proyectos de reforma no exentos de cierto tono liberal, proponiendo armonizar las relaciones agrarias a través de censos y enfiteusis para conjugar el peligro de la revolución. En cambio, fueron las necesidades económicas derivadas de la crisis hacendística las que abrieron las puertas a la posibilidad de redención, marcando la pauta que seguirá la revolución liberal. Un

${ }^{26}$ Real Cédula de 15 de septiembre de 1804, en Novísima Recopilación, lib. X, tít. XV, ley XXIII; 1805-1807, V,p. 92.

27 Cédula del Consejo de 17 de Enero de 1805, en Novísima Recopilación, lib. X, tít. XV, ley XXIV; 1805-1807, V, pp. 92-98, cita en p. 93. 
contrapunto entre teoría y praxis que también heredarán los legisladores liberales del siglo XIX, cuyos programas tuvieron que atravesar el tamiz de la realidad del país, con obstáculos, resistencias y condicionantes que, en cierta medida, encauzaron la actuación política por unos determinados derroteros y no otros.

\section{Hacia la revolución liberal: permanencias y cambios}

No obstante, no fueron únicamente las medidas desamortizadoras las que afectaron a censos y enfiteusis, sino que las sucesivas leyes que declararon la abolición del régimen feudal repararon en este punto, habida cuenta de que este tipo de derechos tenían en el señorío su marco de aplicación. Es por ello que las Cortes de Cádiz establecieron el precedente básico a este respecto en su decreto de abolición de señoríos de 6 de agosto de 1811: atribución de antigua jurisdicción de los señores a la nación y respeto de señoríos territoriales y solariegos como «derechos de propiedad particular». Bajo estos principios, la subsistencia de censos y otros derechos «de esta especie» - alusión velada a la enfiteusis - bajo fórmula contractual no alteraba sustancialmente su naturaleza. A ello apunta la propia ambigüedad del texto al presentarlos junto con otras formas de explotación bien distintas como los arrendamientos, y tal extremo es confirmado por su permanencia en vigor tras la restauración absolutista. En cualquier caso, esta disposición abría camino hacia lo que se produciría más adelante: la ley antiseñorial de 3 de mayo de 1823 volvía a enunciar esa supervivencia, pero «sin fuero ni privilegio alguno»-eliminando toda connotación de feudalismo que pudiesen tener- y declarando la posibilidad de la redención de la enfiteusis «de señorío», pero no del foro, según las medidas anteriores de 1805, hasta que se determinase un marco jurídico más explícito con la redacción de un Código Civil. Claro está que esta medida no tuvo una inmediata continuidad, pero fue restablecida el 2 de febrero de 1837, si bien reinterpretada con la ley definitiva de agosto de 1837, que parecía volver a los términos de la de 1811 al eliminar toda referencia a «fuero y privilegio» y evitar el asunto del Código Civil ${ }^{28}$. Sin duda, son los distintos contextos los que explican estas variaciones, y la

${ }^{28}$ Las leyes de 6 de agosto de 1811, 3 de mayo de 1823 y 26 de agosto de 1837, las recoge Hernández Montalbán, 1991, pp. 415-422. 
fórmula final, que puede definirse como «de compromiso», tiene mucho que ver con las dificultades de asentar el liberalismo en la década de 1830 , en medio de una guerra civil, y con la necesidad de establecer un consenso con la antigua nobleza.

En paralelo a las anteriores medidas, el régimen liberal desarrolló una legislación desamortizadora que hereda motivaciones anteriores -el auxilio a una Hacienda maltrecha-, pero bajo presupuestos inéditos. A este respecto cabe citar, a mitad de camino entre lo que se daba en el Antiguo Régimen y lo que se consolidará en la definitiva revolución liberal, una de las disposiciones del decreto de 9 de noviembre de 1820 , relativo al pago de la deuda pública, que se hacía eco de lo dispuesto en 1805 . Siempre bajo los supuestos de la desamortización, y no más allá, pues no es una declaración general de posibilidad de redención, aparecen ahora los foros dentro de las cargas que pueden liberarse:

Los censos consignativos y reservativos, enfiteusis, foros, misas y pensiones, y toda carga perpetua o temporal que pertenezca a la Nación o al Crédito público por la reforma de los regulares, bienes de patrimonio Real, pertenencias a la Inquisición, redención de cautivos, temporalidades de los jesuitas, obras pías, santuarios, memorias y fundaciones, que están aplicadas y se apliquen al pago de la deuda pública, y graviten sobre bienes y rentas de dominio particular, podrán redimirse con créditos consolidados ${ }^{29}$.

No obstante, habrá que esperar a la desamortización de Mendizábal, con su continuación en el Trienio Esparterista, para una aplicación práctica y de cierta continuidad de una desamortización de censos. Bien conocidas son las circunstancias en que se da esta medida; menos que se integraba en un plan general que pretendía asentar de forma definitiva el liberalismo y que su propósito específico de saneamiento económico era a largo plazo. Claro que la premisa de todo ello, la pronta derrota carlista, no se cumplió, y la eventualidad se impuso sobre la teoría ${ }^{30}$. Aquí no nos interesa tanto comentar el famoso decreto de desamortización de 19 de febrero de 1836 como su alternativa más sonada, la que ideó el economista asturiano Álvaro Flórez Estrada, que trae a colación el tema de los censos enfitéuticos.

29 Decreto de 9 de noviembre de 1820, en Colección de los decretos y órdenes que han expedido las Cortes Generales y Extraordinarias, 1821, IV, pp. 389-390.

${ }^{30}$ Fontana, 1977, pp. 147-148. 
El plan de Flórez Estrada no se trata de una mera réplica a Mendizábal ni se formula como tal, más bien consiste en la aplicación práctica al problema social - y el problema social en un país rural se identifica con la cuestión agraria - de todo un desarrollo teórico en la economía política que realiza un liberal de hondas raíces ilustradas. Con estos antecedentes, es evidente que el asturiano compartía la vocación desamortizadora de Mendizábal, pero consideraba «sumamente perjudicial y equivocado el medio que adopta» ${ }^{31}$. Según Flórez Estrada, los bienes nacionales eran la hipoteca de la deuda pública y enajenarlos suponía privar a unos acreedores de esa hipoteca mientras se saldaba la deuda con otros. Sin embargo, se trata de un argumento formalista e imposible desde todo punto de vista jurídico: el Estado administra los bienes nacionales, pero no le pertenecen - pertenecen a la nación - y, por tanto, no puede constituir sobre ellos hipoteca alguna como garantía del pago de dicha deuda. Los argumentos de peso, si es que hubo tales, se desprenden de sus nociones de economía política que oscilan entre las Luces y el liberalismo.

Flórez Estada parte del principio de Adam Smith de que el trabajo es el fundamento de toda riqueza, por lo que la apropiación de la tierra por una minoría lleva a que la mayoría se vea privada de trabajo o a que su trabajo no se vea correspondido con la recompensa apropiada, de lo que se derivan todas las convulsiones sociales. En consecuencia, las leyes positivas de propiedad son justas cuando corroboran la ley natural de que toda riqueza procede del trabajo:

Examinados con arreglo a estos principios, irrecusables para el economista, los efectos del derecho de propiedad, hallaremos que, cuando este se limita estrictamente a los objetos que son producto del trabajo, la idea de los que le consideran como orijen de todos los progresos físicos i morales de la sociedad es exacta en todas sus partes. [...] Entonces las leyes positivas concernientes a protejer la propiedad son más justas i necesarias de cuantas se conocen, porque su efecto se limita a corroborar la ley natural, de la que nadie puede apartarse sin queden desatendidas las verdaderas necesidades, así del individuo como de la sociedad $^{32}$.

31 Álvaro Flórez Estrada, «Del uso que deba hacerse de los bienes nacionales», El Español, 28 de febrero de 1836.

${ }^{32}$ Flórez Estrada, 1839, p. 8. 
El problema social, sigue argumentando Flórez Estrada, se precipita cuando los dones naturales son propiedad particular, pues es a partir de ellos y mediante el trabajo como se genera la riqueza. Si las leyes civiles de propiedad sancionan esa situación, contraria a la ley natural, son origen de injusticias y graves daños. A partir de ese contraste tan característico del liberalismo español más temprano entre iusnaturalismo e iuspositivisto, Flórez Estrada reformula el sentir ilustrado contradictorio hacia la propiedad. Y en su solución al problema vuelve a recuperar una propuesta ilustrada, la enfiteusis, con un criterio de aplicación también muy propio de las Luces: no actuar en oposición violenta y frontal hacia unos para beneficiar a otros, sino «lentamente i sin lastimar ninguno de los intereses creados» ${ }^{33}$.

Bajo esas premisas, el proyecto del asturiano consistía un sistema de «arriendos enfitéuticos» por parte del Estado de las fincas nacionalizadas, de manera que fuesen cultivadas por colonos que abonasen un canon periódicamente. Según Flórez Estrada, era la solución más justa al conciliar los intereses de todas las clases sociales: además de asegurar al Estado una fuente de financiación fija para atender la deuda, se beneficiaría a un número abundante de cultivadores, y evitaría la devaluación de la renta de la tierra que ya percibían los propietarios, que es exactamente lo que acabaría ocurriendo al poner en el mercado una ingente oferta de tierras. Por otro lado, siguiendo la relación causal entre trabajo y riqueza, las fincas podrían ser mejoradas y aumentar su valor, lo que otorgaba mayor credibilidad al Estado, que conseguiría ir atendiendo a los acreedores de manera cada vez más eficaz, al tiempo que la prosperidad de la agricultura repercutiría positivamente en los demás propietarios. Asimismo, este sistema se podía poner en marcha inmediatamente, mientras que las ventas requerían un proceso complejo y lento. En ello se jugaba el gobierno un tiempo precioso, no solo para aumentar sus ingresos, sino para extender la base social del régimen liberal con los beneficiarios del dominio útil. Finalmente, y continuando el orden de prioridades de Flórez Estrada, la enfiteusis mejoraría la suerte de «la desgraciada clase proletaria».

Llama poderosamente la atención que de lo que trataba nuestro economista era de «arriendos enfitéuticos», esto es, la unión de dos figuras jurídicas distintas, similares pero con diferencias. Andrés Borrego lo re-

33 Flórez Estrada, 1839, p. 17. La herencia ilustrada de Flórez Estrada es puesta de relieve por Lancha, 1984, pp. 209-235. 
cordaba desde su periódico, El Español: «El enfiteusis no es un arrendamiento, como le ha imaginado el Sr. Flórez Estrada». Señalaba Borrego que mientras el arrendatario tiene un uso temporal y limitado, el enfiteuta dispone de la finca, pudiéndola vender, hipotecar o enajenar. El periodista no se detiene en la posible naturaleza feudal de la enfiteusis, pero sí advierte que los derechos de tanteo y laudemio perjudican al censualista «en cuanto entorpecen la libre circulación de las fincas enfitéuticas, que está probado deben ganar de valor en cada traslación de dominio» ${ }^{34}$. Curiosamente, Borrego no tiene ningún problema en ver enfiteusis en «libre circulación» por el mercado y, es más, para favorecerlo, insinúa la idoneidad de eliminar dos derechos definitorios de la enfiteusis desde tiempo inmemorial. En cambio, las resonancias feudales son resaltadas por el propio Flórez Estrada. Según este, el feudalismo tenía dos bases: la primera, que el monarca era titular del dominio directo de toda la tierra; la segunda, que tenía la facultad de distribuir el dominio útil a discreción. La última era perjudicial, pero no la anterior, que se desprendía del propio derecho natural de que no cayesen los dones naturales en manos privadas ${ }^{35}$.

¿Cómo evaluar todo esto? Asistimos a la progresiva transformación de un derecho de contenido señorial como la enfiteusis, que se va asemejando al arrendamiento. Son derechos reales jurídicamente diferentes, como escribía Andrés Borrego, pero, al quedar abolido el señorío, la enfiteusis no es ya objeto de recelo por parte del liberalismo. Flórez Estrada la incluye sin problemas en su propuesta, y sus argumentos nunca se salen del cauce del pensamiento burgués. Precisamente es en este pensamiento, y en eso coinciden todos los estudiosos, donde falla su idea. Esa reforma - su proyecto es una reforma ilustrada en el contexto liberal - requería necesariamente una movilización en el campo que presionase en tal sentido, pero no existía una conciencia campesina ni mucho menos entraba dentro de los planes de la burguesía liberal suscitar tal movimiento ${ }^{36}$. Flórez Estrada miraba al pasado, era un hombre de otro tiempo, un septuagenario que pretendía llevar a cabo una reforma ilustrada. Pero esto no es lo que limita su proyecto; el problema no es que la enfiteusis fuese a contracorriente del principio de propiedad individual ${ }^{37}$. La cuestión es de impo-

\footnotetext{
34 Andrés Borrego, «Sobre dar en enfiteusis los bienes nacionales», El Español, 7 de marzo de 1836.

35 Flórez Estrada, 1836.

36 Tomás y Valiente, 1971 p. 95; Fontana, 1977, p. 271; Lancha, 1984, pp. 214-215.

37 Es uno de los argumentos de Rueda, 2004.
} 
sibilidad práctica: el contexto impedía que fuera más allá de la letra escrita.

Sin embargo, aquí lo que nos interesa es evaluar la propuesta de Flórez Estrada en relación con el tema de la enfiteusis. Lo que refleja, de forma más o menos clara - porque ni siquiera se trata de un plan definido-, es que la enfiteusis ya había entrado plenamente en los marcos del liberalismo. Desde luego, la expresión de «arriendos enfitéuticos» no es especialmente clarificadora a este respecto, pero sí reveladora: a la enfiteusis se le va asignando los caracteres formales de un arrendamiento. Josep Fontana ha señalado agudamente una «metamorfosis camaleónica» del feudalismo al respecto de su conversión en censo ${ }^{38}$. Ello se confirma con el desarrollo seguido hasta aquí: el doble proceso de abolición de señoríos y desamortización afectaron de forma significativa a una institución que ya había sido asemejada a los censos en el propio Antiguo Régimen. En 1837, el vademecum jurídico de Eugenio de Tapia recogía, por vez primera en la jurisprudencia, el enfitéutico dentro de los censos ${ }^{39}$.

\section{La desamortización de censos de Mendizábal a Madoz}

El 5 de marzo de 1836 la reina regente María Cristina de Borbón firmaba el real decreto sobre redención de censos que gravasen los bienes nacionales, es decir, aquellos que se había atribuido el Estado por medio de la desamortización. Así, el artículo primero enunciaba lo siguiente:

Se declaran en estado de redención desde ahora todos los censos, imposiciones y cargas, de cualquier especie y naturaleza, que pertenezcan a las Comunidades de Monacales y Regulares, así de varones como de religiosas, cuyo monasterios o conventos hayan ya sido, o sean en adelante suprimidos, y sus bienes de todo género aplicados a la Nación y mandados vender por mi Real decreto del 19 del mes pasado ${ }^{40}$.

La redacción parece incluir el foro y la enfiteusis, «no obstante su perpetuidad», como efectivamente confirmaba la real orden de 10 de abril

38 Fontana, 1977, pp. 296-299.

39 Tapia, 1837, II, p. 256.

40 Real Decreto de 5 de marzo de 1836, Gaceta de Madrid, 7 de marzo de 1836. 
del mismo año ${ }^{41}$. Hasta el momento, el procedimiento marcado hacía referencia a que el capital de la redención se establecería según las leyes vigentes, y que si el censatario no estaba interesado el censo se enajenaría en pública subasta. Únicamente se establecía en el decreto de 5 de marzo cómo se debía realizar el pago, en plazos - una quinta parte al contado y las otras cuatro anualmente en los años siguientes - y especies de deuda - una tercera parte en vales no consolidados, otra en títulos de deuda corriente con interés y la última en títulos de deuda sin interés pero por la mitad de su valor nominal - . Otra real orden de 18 de septiembre aclaraba algunos aspectos para la redención de pensiones en especies y, entre otras cuestiones de trámite, permitía la redención en metálico ${ }^{42}$. En mayo del año siguiente, las Cortes decretaban que también podían ser objeto de redención los arrendamientos anteriores a $1800^{43}$, evidente asimilación entre arrendamientos de larga duración, enfiteusis y foro. Sin embargo, y a pesar de su progresiva asimilación a los censos, este decreto establecía que el pago debía hacerse en títulos del 4 o 5 por 100 o su equivalente en metálico según su valor en la bolsa de Madrid, lo que representaba una desventaja frente a los medios de pago que se observaban para los censos en el primer decreto.

Lo que parece perfilarse en este desarrollo legislativo fragmentado es que la desamortización de censos no constituía uno de los puntos de atención del Gobierno. Ni tampoco se pretendía allanar el acceso del cultivador a la propiedad con unos plazos insuficientes para una economía campesina, que además presentaban una clara desventaja frente a los que se habían establecido para la venta. Asimismo, la capitalización del precio de redención apuntaba en tal dirección. Mientras que la Instrucción de 9 de junio de 1837 establecía un 3\% de capitalización tanto para censos consignativos y reservativos como para cargas perpetuas - censos enfitéuticos-, la real orden de 23 de abril de 1838 diferenciaba estas últimas con una capitalización de un 1,5\%, con efectos retroactivos ${ }^{44}$. Eso significaba que quienes tenían propiedades afectas con censos reservativos y consignativos debían pagar su renta multiplicada por 33 anualidades, mientras que los que disfrutaban de un dominio útil habían de pagar el

\footnotetext{
${ }^{41}$ Real Orden de 10 de abril de 1836, Gaceta de Madrid, 16 de abril de 1836.

42 Real Orden de 28 de septiembre de 1836, Gaceta de Madrid, 1 de octubre de 1836.

43 Decreto de 28 de mayo de 1837, Gaceta de Madrid, 5 de junio de 1837.

${ }_{44}$ Real Orden de 23 de abril de 1838, en Colección de las leyes, decretos y declaraciones de las Cortes, 1839, XXIV, pp. 172-173.
} 
doble, 66 anualidades, para adquirir el dominio directo y, con él, la plena propiedad $^{45}$. En suma, y a pesar de las prórrogas posteriores para que los censatarios redimieran los censos, no fue la desamortización de Mendizábal y Espartero propicia para la redención de censos, sino que muchos de ellos acabaron siendo subastados ${ }^{46}$.

No obstante, parece haber un cambio de tendencia durante esta misma etapa desamortizadora en el cambio a la década de 1850 y que protagoniza la desamortización de censos de la Orden de San Juan. Los bienes de esta orden se incorporaron al fenómeno desamortizador en 1848, pero en materia de redención de censos los resultados fueron escasos debido a la revalorización del papel de la deuda del 3\%, que era el admitido para parte del pago de redención. En 1851, cuando el gobierno debía atender la amortización del anticipo reintegrable de 100 millones de reales que avalaban los bienes sanjuanistas y que, además, serviría para la negociación de nuevas obligaciones, se estableció una prórroga de cuatro meses para verificar redenciones y una flexibilización en las condiciones de pago. Estas consistían en la posibilidad de pagar una parte de la luición en metálico y, sobre todo, en igualar el tipo de capitalización del 3\% para todos los censos, «tanto en los reservativos y consignativos de origen redimible, como en las demás cargas perpetuas, cualquiera que sea el valor en renta de estas últimas» ${ }^{47}$. Al margen de sus consecuencias inmediatas, sin duda significa un avance en todos los ámbitos que hasta aquí se han descrito: tanto en la progresiva asimilación de los censos enfitéuticos - en el texto todavía se utiliza el término de «cargas perpetuas»- a los otros tipos de censos, como en unas condiciones que favorecen la redención ${ }^{48}$.

La vuelta de los progresistas al poder en julio de 1854 reanudó el fenómeno desamortizador, y con él otro capítulo específico de redención de censos. El espaldarazo que desde la economía política dio Madoz a su

45 Sobre la capitalización de redención de censos y sus diferentes expresiones (al millar, por cien), resulta clarificadora la consulta de Tapia, 1837, IX, pp. 386-388.

46 Véase Villares, 1982, pp. 141-178; Cordero Torrón, 1986; Vallejo Pousada, 1991, 1992 y 1993 , pp. 37-59 y 93-110 para el caso gallego; Moro, 1981b, pp. 91-118, 225-238 y 241-253 para Asturias; Dónezar, 1991, pp. 235-250 y 277-280 para Navarra; Aguado Cabezas, 2002, pp. 268-287 y Ortega Canadell, 1982, pp. 59-62 para Castilla y León; González Marzo, 1989; López Puerta, 1989, pp. 98-199 y Valle Calzado, 2015, pp. 97-104 para Castilla-La Mancha; Lozano, 1986, pp. 169-177 para el caso de Zaragoza; Sánchez Recio, 1986, pp. 59-64 para Alicante; Naranjo Sanguino, 1997, pp. 124-220 para Badajoz.

47 Real Decreto de 7 de marzo de 1851, Gaceta de Madrid, 8 de marzo de 1851.

48 Villares, 1988; Sánchez García, 2015. 
proyecto de desamortización era muy bien conocido dentro de las filas del liberalismo progresista español: el principio de propiedad privada. Había que «salvar» aquellos bienes todavía apresados por «la garra yermadora de la amortización» y «restituir a la propiedad todas aquellas condiciones que hacen de esta institución el fundamento firmísimo de la sociedad civil». Sin embargo, en la exposición de principios del proyecto no se mencionan los censos, y en el articulado ni siquiera se les reserva un apartado específico, sino que figuran en el mismo artículo dedicado a la forma de pago de las subastas:

Art. $3 .^{\circ}$. El pago del remate de las fincas rústicas y urbanas deberá hacerse en metálico y en la siguiente proporción: al contado, 10 por 100 ; en cada uno de los tres primeros años siguientes a la fecha del primer pago, 10 por 100; en cada uno de los cinco años subsiguientes, 6 por 100 , y 5 por 100 en cada uno de los seis restantes.

El pago de los censos a favor de los pueblos se hará en la misma especie y proporción que las fincas rústicas y urbanas, así como el de los pertenecientes al Estado, clero y a las corporaciones y establecimientos de instrucción y beneficencia, siempre que excedan de 500 reales de capital, concediéndose a los compradores o censatarios que rediman los de menor cuantía la rebaja de una tercera parte del precio de subasta, o en defecto de esta, de la capitalización. ${ }^{49}$

El dictamen de la Comisión sobre el proyecto de ley propuso, en cambio, un título - el segundo- concretamente dedicado a la desamortización de censos. En él, los artículos 7., $8 .^{\circ}$ y 9..$^{\circ}$ concedían un plazo para solicitar las redenciones de seis meses desde que se publicase la ley, diferenciando entre aquellas censos cuyo capital excediese los 500 reales, a los que se efectuaría una rebaja de un tercio de capital, y los que no llegasen a tal cantidad, con un rebaja del $20 \%$. El importe de la luición habría de ser satisfecho en los mismos términos y plazos que se establecían para los compradores de fincas, en quince plazos y catorce años y en metálico: $10 \%$ al contado, $8 \%$ en cada uno de los dos años siguientes, $7 \%$ en cada uno de los dos año subsiguientes y $6 \%$ en cada uno de los diez años que restaban. Una vez pasado el plazo de los seis meses, los censos no redimidos se pondrían en venta con las mismas condiciones que las fincas de lidice.

49 Diario de Sesiones de las Cortes Constituyentes, 76 (5 de febrero de 1855), apén- 
citación pública, si bien se contemplaba una rebaja de un 30\% para aquellos cuyo capital fuese inferior a 500 reales $^{50}$.

Después de sucesivas enmiendas presentadas por distintos diputados al título segundo del proyecto ley, a mediados de abril comenzó su discusión en las Cortes Constituyentes, con una intervención de Madoz en la que mostraba su voluntad por conciliar todos los intereses en esta materia, pero sentando el principio irrenunciable de hacer efectiva la desamortización de censos por la vía de la redención ${ }^{51}$. Esto quedó de manifiesto en algunos de los discursos del ministro de Hacienda, como el que dirigió en respuesta a la queja del diputado Antonio de Jesús Arias, que sostenía que, en materia de censos, la ley de desamortización era una «ley de expoliación» en contra de las instituciones de beneficencia y a favor de los especuladores. La expresión causó gran escándalo en las Cortes, y Madoz le contestó que el capítulo de la redención de censos era esencial para el Estado, no tanto por el beneficio directo que pudiese obtener, sino con el que hacía al censatario librándole de la renta anual que debía satisfacer, y que a su vez repercutía en el aumento de la riqueza imponible. Este principio de redención se limitaba a los bienes desamortizados, pues los censos «de particulares» se ordenarían según la legislación antiseñorial vigente, pero constituía un mecanismo fundamental para asentar el régimen liberal de forma efectiva: «aquí lo que debe procurarse es quitar gravámenes y aumentar la materia imponible, a fin de que la revolución no sea una palabra estéril, a fin de que la revolución no se reduzca a poder leer ocho o diez periódicos u ocho o diez discursos que se pueden hacer cada día, sino que tenga un resultado real y positivo» ${ }^{52}$.

Respecto a los proyectos previos, el título segundo de la ley de desamortización. El cambio más significativo era que la capitalización ya no dependería del capital del censo sino de los réditos anuos que de él se devengaban: aquellos que no excediesen los 60 reales anuos se capitalizarían al $10 \%$, verificando el pago al contado; en caso de una renta mayor, la capitalización sería al $8 \%$ si el pago era al contado o al 5\% si era a nueve años y diez plazos. En caso de que su interés superase el $5 \%$ por su naturaleza especial (algo poco frecuente pues en el siglo XVIII el tipo de interés se había reducido al 3\%), la redención se efectuaría según el tipo que indice.

${ }^{50}$ Diario de Sesiones de las Cortes Constituyentes, 89 (23 de febrero de 1855), apén-

51 Diario de Sesiones de las Cortes Constituyentes, 136 (23 de abril de 1855), p. 4071.

52 Diario de Sesiones de las Cortes Constituyentes, 138 (25 de abril de 1855), p. 4148. 
dicase la escritura de imposición. La distinción entre los distintos réditos en su capitalización apunta a un intento de equilibrar los intereses económicos de la Hacienda con la posibilidad de que los censatarios redimiesen sus cargas, lo que parece ser confirmado por la condonación de atrasos no reclamados en los últimos cinco años. Asimismo, se concedía un plazo de seis meses para solicitar la redención, después sucesivamente ampliado por la legislación. Finalmente, la Instrucción del 31 de mayo de 1855 en su título VIII organizó toda la dimensión procedimental de la desamortización de censos ${ }^{53}$.

Ya en esta ley no aparece el término «enfiteusis», definitivamente incorporado a los censos, si acaso cabía alguna duda de ello. En cambio, se hace mención a «foros» $\mathrm{y}$ «treudos». La distinción es intencionada, y esboza cierta asimilación entre una enfiteusis propia de Galicia y perpetuada por la disposición de 1763, y otra propia de Aragón que se creía perpetua. Continúa así la línea abierta desde finales del siglo XVIII por los propios intermediarios para despejar cualquier duda de perpetuidad. Siendo el Estado el último titular del dominio directo de los foros, su redención por el intermediario prolongaba la división de dominios, pero en inmejorables condiciones para este: pasaba a ser el titular directo del foro, mientras que al cultivador titular del útil no le cabía la posibilidad de redimir su canon, que era irredimible, no obstante su perpetuidad. La antigua hidalguía intermediaria se perfilaba así como una burguesía agraria perceptora de rentas en Galicia y sus zonas limítrofes.

Por otra parte, su duración, que, exceptuado el paréntesis de 18561858, se extiende hasta la aprobación del Estatuto Municipal en 1924, hace pensar que fue la fase desamortizadora en la que se produjo un mayor número de luiciones de censos, extremo en el que coincide toda la bibliografía ${ }^{54}$. Tras la suspensión de la desamortización después del bienio progresista, la redención de censos no se reanudó inmediatamente junto al resto del proceso, sino que el Gobierno esperó a tramitar una nueva ley que estableciese nuevas capitalizaciones más beneficiosas para el Estado.

${ }^{53}$ La ley de 1 de mayo de 1855 y la instrucción para su cumplimiento de 31 de mayo de 1855, en Gaceta de Madrid, 3 de junio de 1855, suplemento.

54 Véase Artiaga, 1988, 1991, pp. 229-270; Villares, 1988; y Cordero Torrón, 2016 para Galicia; Moro, 1981a para Asturias; Bilbao Díez, 1983, pp. 119-135 sobre el partido judicial de Logroño; Díez Espinosa, 1986b, pp. 273-336; Castrillejo Ibáñez, 1987, pp. 177195; y Ortega Canadell, 1982, pp. 179-185 para Castilla y León; González Marzo, 1990 y 2008 para Castilla-La Mancha; Vázquez Guzmán, 2011 para la provincia de Almería. 
Así, la ley de 11 de marzo de 1859 del ministro de Hacienda Pedro Salaverría encareció las capitalizaciones, tanto en las rentas inferiores a 60 reales, que ahora se capitalizarían al 8\%, como en las de mayor cuantía que se redimiesen al contado, que se elevaban al 6,5\%. Se concedía, no obstante, que los censatarios que hubiesen solicitado la redención antes del 14 de octubre de 1856 (fecha de la Real Orden que suspende la desamortización) se pudiesen acoger a los tipos de capitalización, más baratos, de la legislación anterior ${ }^{55}$.

\section{Conclusiones}

La legislación analizada no deja lugar a dudas: los censos no fueron instituciones feudales dentro del régimen liberal. En primer lugar, porque ni siquiera todos los censos y enfiteusis tenían contenidos feudales, sino que en muchos casos estas figuras se establecían en un sentido contractual antes incluso de la caída del Antiguo Régimen, a pesar de que la enfiteusis mantuviera aspectos que evocan el feudalismo como el tanteo, el laudemio o el comiso. Pensemos, por ejemplo, en los censos que se instituían libremente entre particulares, o los que resultaron de las enajenaciones de bienes de propios a canon enfitéutico o reservativo. Por el contrario, en aquellas enfiteusis que revestían connotaciones señoriales porque tenían lugar en el marco del señorío, la legislación antiseñorial actuó vaciándolas de tal significado y reconvirtiéndolas en propiedad particular. No obstante, no olvidemos que el cambio tuvo sus límites: aquellos que quisieron imponerse los dirigentes liberales y los que les pudieron imponer las fuerzas contrarias. Esto significa, en lo que se refiere a este tipo de instituciones en los antiguos señoríos, que no se alteraron los papeles de explotados y explotadores, si bien después de la revolución liberal la explotación se daba en el marco de una relación contractual.

Una vez decretada la abolición de los señoríos, con todas sus limitaciones, la enfiteusis no despertó demasiadas suspicacias a los liberales, como demuestra la idea de los «arriendos enfitéuticos» de Flórez Estrada, que reconocía las bases feudales de la enfiteusis. Sin embargo, la propia expresión es bastante sintomática de lo que se entendía por enfiteusis en la década de 1830, al igual que la propuesta de Andrés Borrego - aunque

55 Ley de 11 de marzo de 1859, Gaceta de Madrid, 12 de marzo de 1859. 
desde una opinión contraria a Flórez Estrada - de potenciar la «libre circulación» de estas instituciones. La asimilación de arrendamientos antiguos y enfiteusis a efectos de posibilitar su redención con la legislación desamortizadora también apunta en esta dirección, al tiempo que la enfiteusis se integraba definitivamente en el capítulo de los censos.

La desamortización de censos fue inspirada por el principio de "propiedad perfecta», y en este sentido fue orientada la normativa referente a las redenciones. Sin embargo, su alcance dependió de las circunstancias que atravesaba la revolución liberal. Esta vía desamortizadora no fue potenciada lo suficiente en la fase desamortizadora de Mendizábal debido a que lo que obsesionaba al Gobierno eran las subastas de lotes de tierras para superar la situación crítica de la economía y allegar recursos para vencer el carlismo. Los plazos insuficientes, los tipos de capitalización onerosos - que además diferenciaban entre censos y enfiteusis - y el pago en títulos de deuda o su equivalente en metálico según su valor en la Bolsa dificultaron la actuación de los censatarios. No fue hasta la década de 1850, una vez asentado el liberalismo, cuando la desamortización de los bienes de la Orden de San Juan estableció unas condiciones más propicias para la redención. El regreso al poder de los progresistas en 1854, en cambio, hizo de la redención de censos un capítulo fundamental del proceso desamortizador. Los progresistas pretendían un salto cualitativo que afianzase económicamente el nuevo sistema, y ello pasaba por favorecer el acceso de los llevadores de censo a la propiedad completa de las tierras gravadas, y ello no se debía a que estas instituciones tuviesen algo de «feudalismo», sino a que su redención implementaba una nueva configuración económica acorde a los nuevos tiempos y a los intereses fiscales del Estado. Eso era para Madoz el «resultado real y positivo» de la palabra revolución, que iba más allá de un cambio político para afectar las estructuras sociales y económicas en sus mismos fundamentos ${ }^{56}$.

Precisamente, en este punto, los censos nos presentan una contradicción en aquellos momentos de derrumbe del absolutismo y afianzamiento del orden liberal. Por una parte, los ilustrados pensaron que estas instituciones podían mitigar los efectos de la amortización y la vinculación características de la propiedad en el Antiguo Régimen sin alterar sustancialmente sus bases, pero fue precisamente a finales del siglo XVIII cuando la

56 Sobre la necesidad de subrayar las dimensiones sociales de la «revolución burguesa», véase Davidson, 2013, pp. 17-24. 
legislación empezó a contemplar su redención. Por otro lado, los liberales que buscaban el horizonte de la propiedad perfecta no implementaron medidas efectivas para su redención hasta la mitad de la centuria. A largo plazo, hay que tener en cuenta que los censos actuaron en uno y otro sentido de la desamortización: primero con la enajenación de los bienes amortizados a canon y luego con su redención. Aquí radica precisamente su virtualidad de transformación. El cambio jurídico, así, devino en cambio social.

\section{Bibliografía}

Aguado Cabezas, Elena, La desamortización de Mendizábal y Espartero en la provincia de León (1836/1851), Universidad de León, León, 2002.

ArTIAGA, Aurora, «As redencions de censos e foros no proceso desamortizador, 1855-1908», en Villares, Ramón, ed., Donos de Seu. Estudios de historia agraria en Galicia, Sotelo Blanco, Barcelona, 1988, pp. 103-142.

Artiaga, Aurora, A desamortización na provincia de Pontevedra (1855-1900), Diputación Provincial, Pontevedra, 1991.

Bilbao Díez, Juan Carlos, La desamortización de Pascual Madoz en la ciudad de Logroño y su partido judicial (1855-1856). Aportación al estudio de la propiedad en la zona a mediados del siglo XIX, CSIC/Instituto de Estudios Riojanos, Logroño, 1983.

Castrillejo IbáÑEz, Félix María, La desamortización de Madoz en la provincia de Burgos (1855-1869), Universidad de Valladolid, Valladolid, 1987.

Clavero, Bartolomé, «Enfiteusis, ¿qué hay en un nombre?», Anuario de Historia del Derecho Español, 56, 1986, pp. 467-519.

Clavero, Bartolomé, «Foros y rabassas. Los censos agrarios ante la revolución española» (dos partes), Agricultura y Sociedad, 16, 1980 y 18, 1981, pp. 27-69 y 65-100.

Clavero, Bartolomé, «Prohibición de la usura y constitución de rentas», Moneda y Crédito, 143, 1977, pp. 107-131.

CódIGo DE LAS SIETE PARTIDAS, tomos II-IV de Los códigos españoles concordados y anotados, Imprenta de la Publicidad, Madrid, 1848, 3 vols.

COLECCIÓN DE LAS LEYES, decretos y declaraciones de las Cortes, Imprenta Nacional, Madrid, 1839, vol. XXIV.

COLECCIÓN DE LOS DECRETOS Y ÓRDENES QUE HAN EXPEDIDO LAS CORTES GENERALES Y EXTRAORDINARIAS, Imprenta Nacional, Madrid, 1821, vol. IV.

Congost, Rosa: «Sagrada propiedad imperfecta. Otra visión de la revolución liberal española», Historia agraria. Revista de agricultura e historia rural, 20, 2000, pp. 61-93. 
CORDERO TORRÓN, Xosé, «La redención foral en la provincia de La Coruña ante el proceso desamortizador», en Desamortización y Hacienda Pública, Instituto de Estudios Fiscales, Madrid, 1986, vol. I, pp. 191-206.

CORDERo TORRón, Xosé, «Los foros en la desamortización. Etapas de Mendizábal y Madoz», Revista Galega de Economía, 25/1, 2016, pp. 35-51.

CORDERo TORRón, Xosé, La desamortización de los censos en España. Etapas de Mendizábal y Madoz, Santiago de Compostela, 2012, en CD.

CoRNEJo, Andrés, Diccionario histórico, y forense del Derecho real en España, D. Joachín Ibarra, Madrid, 1779-1784, 2 vols.

Covarrubias, Sebastián de, Tesoro de la lengua castellana, Luis Sánchez, Madrid, 1611.

DAVIDSON, Neil, Transformar el mundo: revoluciones burguesas y revolución social, Pasado \& Presente, Barcelona, 2013.

Díez Espinosa, José Ramón, «La desamortización de censos», Ayer, 9, 1993, pp. 61-104.

DíEZ ESPINOSA, José Ramón, «La desamortización de censos», en RUEDA, Germán; García Colmenares, Pablo y Díez Espinosa, José Ramón, La desamortización de Mendizábal y Espartero en España, Cátedra, Madrid, 1986a, pp. 76-84.

Díez EsPINosa, José Ramón, Desamortización y economía agraria castellana: Valladolid, 1855-1868, Institución Cultural Simancas, Valladolid, 1986b.

DonÉZAR, José María, Navarra y la desamortización de Mendizábal (1836-1851), Gobierno de Navarra, Pamplona, 1991.

Elizondo, Francisco Antonio de, Práctica universal forense de los tribunales de España, y de las Indias, Viuda e Hijo de Marín, Madrid, 1792, vol. IV.

FIESTAS LOZA, Alicia, «El censo consignativo según una fórmula castellana del Antiguo Régimen», Anuario de Historia del Derecho Español, 63-64, 19931994, pp. 549-614.

FlóREZ Estrada, Álvaro, Contestación de Don Álvaro Flórez Estrada a las impugnaciones hechas a su escrito sobre el uso que deba hacerse de los bienes nacionales, Miguel de Burgos, Madrid, 1836.

FLóREZ EstradA, Álvaro, La cuestión social, o sea origen, latitud y efectos de Derecho de propiedad, Miguel de Burgos, Madrid, 1839.

FonTANA, Josep, La revolución liberal: política y hacienda en 1833-1845, Instituto de Estudios Fiscales, Madrid, 1977.

Gómez Oliver, Miguel y GonzÁlez De Molina, Manuel, «Crisis fiscal y mercado de tierras. A propósito de la desamortización de Godoy en Andalucía», en Donézar, Javier María y Pérez Ledesma, Manuel, eds., Antiguo Régimen y liberalismo. Homenaje a Miguel Artola, Alianza, Madrid, 1995, vol. II, pp. 199-221.

GonZÁlez MARzo, Félix, «Redención y venta de censos y arrendamientos en la provincia de Cuenca, durante la desamortización de Mendizábal», Cuenca, 33, 1989, pp. 101-113. 
¿Un vestigio feudal dentro del régimen liberal?

GonzÁlez Marzo, Félix, La desamortización de Madoz en la provincia de Cuenca (1855-1886), Universidad Autónoma de Barcelona, Barcelona, 1990.

GonzÁlez MARZo, Félix, La desamortización de Madoz en la provincia de Guadalajara (1855-1896), Caja de Guadalajara, Guadalajara, 2008.

Hernández Montalbán, Francisco J., La abolición de los señorios en España (1811-1837), Biblioteca Nueva/Universitat de València, Madrid/Valencia, 1991.

HerR, Richard, «Hacia el derrumbe del Antiguo Régimen: crisis fiscal y desamortización bajo Carlos IV», Moneda y Crédito, 118, 1971, pp. 37-100.

HERR, Richard, La Hacienda Real y los cambios rurales en la España de finales del Antiguo Régimen, Madrid, Instituto de Estudios Fiscales, 1991.

Jove y BRAVo, Rogelio, Los foros: estudio histórico, doctrinal, bibliográfico y crítico de los foros en Galicia y Asturias, Madrid, 1883.

Jovellanos, Gaspar Melchor de, Informe de [...] el expediente de la Ley Agraria, Madrid, 1795.

Ladero QuesadA, Miguel Ángel, «Crédito y comercio de dinero en la Castilla Medieval», Acta Historica et Archaeologica Mediaevalia, 11-12, 19901991, pp. 145-159.

LANCHA, Charles, Álvaro Flórez Estrada (1766-1853) ou le libéralisme espagnol a l'épreuve de l'histoire, Université des Langues et Lettres de Grenoble, Grenoble, 1984.

LlOMBART, Vicent, Jovellanos y el otoño de las Luces. Educación, economía, política y felicidad, Trea, Gijón, 2013.

LóPEZ PuerTA, Luis, La desamortización eclesiástica de Mendizábal en la provincia de Guadalajara, Diputación Provincial de Guadalajara, Guadalajara, 1989.

LozAno, Carmen, Estudios sobre la desamortización en Zaragoza, Diputación General de Aragón, Zaragoza, 1986.

MEMORIAL AJUSTADO [...] SOBRE EL ESTABLECIMIENTO DE UNA LEY AGRARIA [...], Madrid, 1784.

MerChÁN Álvarez, Antonio, La reforma agraria en Andalucía: el primer proyecto legislativo (Pablo de Olavide. Sevilla 1768), Universidad de Sevilla, Sevilla, 1997.

Mora CAÑAdA, Adela, «Unas notas sobre los Comentarii de Censibus (15941605) de Feliciano de Solís», en Universidades españolas y americanas, Generalitat Valenciana, Valencia, 1987, pp. 403-414.

Moro, José María, «La desamortización de Madoz en Asturias», Estudios de Historia Social, 18-19, 1981a, pp. 85-165.

Moro, José María, La desamortización en Asturias, Silverio Cañada, Oviedo, 1981b. 
Naranjo Sanguino, Miguel Ángel, La desamortización de Mendizábal-Espartero en la provincia de Badajoz (1836-1852), Diputación Provincial de Badajoz, Badajoz, 1997.

Naranjo Sanguino, Miguel Ángel y Roso Díaz, Manuel, «Aproximación a la desamortización de Godoy en la región de Extremadura», en Manuel Godoy y su tiempo. Congreso internacional, Editora Regional de Extremadura, Mérida, 2003, vol. I, pp. 301-326.

NovísIma RECOPILACIÓN DE LAS LEYES DE ESPAÑA, Imprenta de Sancha, Madrid, 1805-1807, 6 vols,

Ortega Canadell, Rosa, Las desamortizaciones de Mendizábal y Madoz en Soria, Caja General de Ahorros y Préstamos, Soria, 1982.

OrtuÑo SÁnChEZ-PEDREÑo, José María, «Origen romano de la enfiteusis en las Partidas», Anales de la Universidad de Alicante. Facultad de Derecho, 8, 1993, pp. 63-73.

Perdices Blas, Luis, «El desarrollo intelectual de Jovellanos en la Sevilla de Olavide (1768-1776)», Dieciocho: Hispanic Enlightenment, 36/1, 2013a, pp. 51-78.

Perdices Blas, Luis, «La agricultura en la empresa colonizadora de Pablo de Olavide», en Estructuras agrarias y reformismo ilustrado en la España del siglo XVIII, Ministerio de Agricultura, Pesca y Alimentación, Madrid, 1989b, pp. 585-599.

Pereira IgLeSIAS, José Luis, «El censo consignativo en el pensamiento económico de la España moderna», Trocadero: Revista de Historia Moderna y Contemporánea, 6-7, 1994-1995, pp. 139-160.

Peset, Mariano y Blasco, Yolanda, «Redención y extinción de censos en el siglo XIX», Saitabi, 42, 1992, pp. 63-79.

RUEDA, Germán, «Álvaro Flórez Estrada y la desamortización», en VARELA SuANZES-CARPEGNA, Joaquín, coord., Álvaro Flórez Estrada (1766-1853): política, economía, sociedad, Junta General del Principado de Asturias, Oviedo, 2004, pp. 439-471.

SALA, Juan Bautista, Ilustración del Derecho Real de España, Joseph de Orga, Valencia, 1803, 2 vols.

SÁNCHEZ GARCÍA, Raquel, «El proceso desamortizador y la Orden de Malta», en Alvarado, Javier y SalazAr, Jaime, coords., La Orden de Malta en España (1113-2013), Sanz y Torres/UNED, Madrid, 2015, vol. I, pp. 445-479.

SÁnchez Recio, Glicerio, La desamortización de Mendizábal en la provincia de Alicante. El clero regular: 1836-1850, Instituto de Estudios Juan Gil-Albert/ Diputación, Alicante, 1986.

Sisternes y Feliu, Manuel, Idea de la ley agraria española, Valencia, 1786.

Solís, Feliciano de, Commentarii de censibvs [...], Juan Gracián, Alcalá de Henares, 1594. 
¿Un vestigio feudal dentro del régimen liberal?

TAPIA, Eugenio de, Febrero novísimo, o librería de jueces, abogados, escribanos y médicos legalistas, Ildefonso Mompie, Valencia, 1837, vols. II y IX.

TomÁs y VAliEnTE, Francisco, El marco político de la desamortización, Ariel, Barcelona, 1971.

Valle CAlzAdo, Ángel Ramón del, El poder de la propiedad. Élites y desamortización en la España interior (Madrid y Castilla-La Mancha), Almud, Toledo, 2015.

Valle CALZAdo, Ángel Ramón del, La desamortización eclesiástica en la provincia de Ciudad Real, 1836-1854, Servicio de Publicaciones de la Universidad de Castilla-La Mancha, Cuenca, 1995.

VALLeJo Pousada, Rafael: «Desamortización de Mendizábal y transformación de la propiedad de la tierra: la redención de censos como vía formal. Pontevedra: 1836-1843», Agricultura y Sociedad, 61 (1991), pp. 97-103.

VALLEJo PousADA, Rafael: «Redención y pervivencia del foro durante la desamortización de Mendizábal (1836-1844)», Anuario de Historia del Derecho Español, 60 (1992), pp. 477-500.

VAllejo Pousada, Rafael, A desamortización de Mendizábal na provincia de Pontevedra, 1836-1844, Diputación Provincial, Pontevedra, 1993.

VÁzQuez GuZMán, Juan Pedro, La desamortización de Madoz en la provincia de Almería (1855-1936), Universidad de Almería, Almería, 2011.

Villares, Ramón, «Desamortización e dereito de propiedade», en ViLlares, Ramón, ed., Donos de Seu. Estudios de historia agraria en Galicia, Sotelo Blanco, Barcelona, 1988, pp. 101-142,

VILLARES, Ramón, «La desamortización de bienes del Clero Regular en la provincia de Lugo, 1837/1851», en Desamortización y Hacienda Pública, Instituto de Estudios Fiscales, Madrid, 1986, vol. I, pp. 563-579.

VILlares, Ramón, La propiedad de la tierra en Galicia, Siglo XXI, Madrid, 1982.

\section{Datos del autor}

David Martínez Vilches (damart06@ucm.es) es Máster en Historia Contemporánea y graduado en Historia por la Universidad Complutense de Madrid, con Premio Extraordinario de Grado y Diploma al mejor expediente académico del Grado de Historia concedido por el Ilustre Colegio Oficial de Doctores y Licenciados en Filosofía y Letras y en Ciencias de la Comunidad de Madrid. Se ha especializado en historia cultural e historia de las culturas políticas. Ha sido becario de colaboración en el Departamento de Historia Contemporánea de la UCM en el curso 20152016 y ha participado en varios congresos científicos y publicaciones. 